DOI 10.37882/2223-2982.2021.04.23

\title{
РОЛЬ МЕДИКО-ГИГИЕНИЧЕСКИХ ЗНАНИЙ В ПРОФЕССИИ ЮРИСТА
}

\section{THE ROLE OF MEDICAL AND HYGIENIC KNOWLEDGE IN THE LEGAL PROFESSION \\ E. Maleichenko \\ M. Skidan \\ A. Natalia}

Summary: The training of young specialists involves the mandatory acquisition of a system of certain knowledge, skills and abilities. The modern life of a student is saturated with extreme conditions, and in order to endure them, while remaining mentally and physically capable, it is necessary to increase their biological, psychophysiological and physical potential. Only then can we expect the most complete professional selfrealization of the extension of creative and physical longevity.

Keywords: professional legal activity, medical and hygienic knowledge, health, adaptation.
Малейченко Елена Алексеевна

К.с.н., Российский государственный университет правосудия Северо-Кавказский филиал, г. Краснодар krasnodarlena@bk.ru

Скидан Мария Николаевна

Преподаватель, Российский государственный университет правосудия Северо-Кавказский филиал, г. Краснодар

Доценко Наталья Анатольевна

Российский государственный университет правосудия Северо-Кавказский филиал, г. Краснодар

Аннотация: Подготовка молодых специалистов предполагает обязательное получение системы определенных знаний, умений и навыков. Современная жизнь студента насыщена экстремальными условиями, и чтобы переносить их, оставаясь умственно и физически работоспособными, необходимо повышать свой биологический, психофизиологический и физический потенциал. Только тогда можно ожидать наиболее полной профессиональной самореализации продления творческого и физического долголетия.

Ключевые слова: профессиональная юридическая деятельность, медико-гигиенические знания, здоровье, адаптация.

В условиях недостатка у большинства населения страны (в большей степени у молодежи) стартовых ресурсов интеграции в рыночные отношения происходит эксплуатация наиболее доступного ресурса - психического и физического здоровья, что доказывает инструментальный характер ценности здоровья. В таких условиях здоровье как ценность воспринимается в качестве средства достижения поставленных целей, а не в качестве средства, обеспечивающего долгую и полноценную жизнь.

В научной литературе значимость физического и психического здоровья предопределена следующими факторами, оказывающими негативное влияние на здоровье людей, для которых юридическая деятельность является профессиональной.

1. Каждое направление профессиональной юридической деятельности характеризуется рядом негативных факторов, влияющих на состояние здоровья. Так, профессиональная деятельность юристов, основное направление деятельности которых связано с гражданским правом, характеризуется большой нагрузкой на свойства памяти, в частности зрительной, слуховой и двигательной; снижается концентрация внимания. Вместе с тем, юристы, осуществляющие профессиональную деятельность в области уголовного права, сталкиваются с повышенной нагрузкой на зрительный 
анализатор, отчего страдает острота зрения и глазомер и др.

2. Профессиональная юридическая деятельность сопряжена постоянным повышением объема программирования и непосредственной работы с электронно-вычислительной техникой (компьютер, ноутбук и т.п.). Вместе с тем, указанные факторы приводят к снижению плодотворности профессиональной юридической деятельности, поскольку такая плодотворность непосредственно зависит от состояния психического и физического здоровья лица, осуществляющего ее.

3. Профессиональная юридическая деятельность опосредована малоподвижностью человеческого тела, что связано с характерной сидячей рабочей позой юриста. Указанное приводит к возникновению ряда проблем, связанных со здоровьем:

- нарушение правильной конфигурации позвоночного столба;

- снижение подвижности в наиболее крупных суставах (плечевом, локтевом, тазобедренном, коленном, голеностопном);

- снижение поступления кислорода к работающим органам, в первую очередь к головному мозгу, вызванное ограниченной подвижностью грудной клетки (снижением глубины дыхания);

- ухудшение нормального тока крови и лимфы в организме, и как следствие, развитие застойных явлений в брюшной полости и нижних конечностях, что вызывает варикозное расширение вен.

- нарушение функции зрения, вызванное каждодневной нагрузкой зрительного анализатоpa.

Знание изложенных рисков и способов их преодоление, а также обладание медико-гигиеническими знаниями, позволит снизить негативное влияние данных факторов.

Роль медико-гигиенических знаний в профессии юриста обусловлена следующим.

Во-первых, профессия юриста связана с высокими психоэмоциональными нагрузками. И. Шмыков, анализируя социально-психологические ресурсы психической устойчивости юристов, указывает на особенность профессии юриста, которая выражается в характеристике ее как стрессогенной, что связано с повышенными профессиональными и личностными требованиями. Среди одного из наиболее значимых требований автор выделяет способность юриста к стрессоустойчивости.

Профессия юриста обусловлена жесткими требованиями к состоянию физического здоровья. Для форми- рования профессии юриста немаловажную роль играют усиление сопротивляемости организма к неблагоприятным факторам, имеющим как природный, так техногенных характер. Сопротивляемость организма повышается посредством активной физической деятельности человека, поэтому роль физической культуры в данной профессии сложно переоценить. Активное занятие спортом позволяет увеличить производительность труда, повысить уровень работоспособности и т.д.

В научной литературе указывается на высокую значимость физического воспитания студентов-юристов. Так, Е.А. Малейченко указывает на неразвитость представления студентов, проходящих обучение по юридической специальности, о здоровом образе жизни. Кроме того, автором обращается внимание на тот факт, что такие студенты, как правило, не связывают установки на здоровый образ жизни с профессиональным статусом юриста.

Во-вторых, юрист имеет постоянные контакты с людьми, что обуславливает необходимость здорового внешнего вида.

Первое впечатление, производимое юристом при встрече с клиентом, может стать барьером для дальнейшего нормального выстраивания нормальной прямой и обратной связи между сторонами. Принципиальное значение в профессиональной деятельности юриста имеет первое впечатление, которое он произвел на потенциального клиента, что предопределяет степень доверия такого лица к юристу. Отсутствие здоровья вызывает постоянный болезненный, страдающий вид, что для юриста означает потерю доверия клиента, поскольку вполне логично, что такой юрист не в состоянии надлежащим образом выполнять свои обязательства перед клиентами. Юридическая деятельность, связанная с обеспечением выполнения государством каких-либо функций, в частности, функций по защите прав, свобод и законных интересов граждан, должна характеризоваться повышенным вниманием к здоровью лиц, осуществляющих такую деятельность. В этой связи, судья, который при выполнении профессиональных обязанностей сталкивается с физической слабостью, вызванной отсутствием здоровья, вынужден прерывать процесс по рассмотрению и разрешению юридических дел, что означает невозможность выполнения его долга перед государством по отправлению правосудия. Следовательно, прямая обязанность судьи заботиться о своем здоровье, поддерживать его. В этом проявляется этическая составляющая юридической профессии.

Изложенное позволяет сделать вывод о роли медико-гигиенических знаний в профессии юриста проявляется в следующем.

Во-первых, наличие указанных знаний позволяет 
снизить влияние негативных факторов, связанных с ухудшением здоровья ввиду осуществления профессиональной юридической деятельности.

Во-вторых, поскольку профессиональная деятельность юриста связана с постоянными психофизическими нагрузками, медико-гигиенические знания позволяют адаптироваться к неблагоприятным факторам деятельности, повысить производительность труда, достигнуть высокой работоспособности.

В-третьих, юрист имеет постоянные контакты с людьми, что обуславливает необходимость здорового внешнего вида.

\section{ЛИТЕРАТУРА}

1. Голубков А.В., Громов В.А. Психофизическая готовность юристов к выполнению профессиональных обязанностей // Известия ТулГУ. Физическая культура. Спорт. 2019. №2. URL: https://cyberleninka.ru/article/n/psihofizicheskaya-gotovnost-yuristov-k-vypolneniyu-professionalnyh-obyazannostey (дата обращения: 22.10.2020).

2. Купцова 0.В., Цукарев А.Е. Нравственные качества юриста // Огарёв-Online. 2017. №3 (92). URL: https://cyberleninka.ru/article/n/nravstvennye-kachestvayurista (дата обращения: 22.10.2020).

3. Малейченко Е.А. Формирование установок на здоровый образ жизни в профессиональной подготовке студентов-юристов: дис. ... канд. социолог. Наук. Волгоград, 2007. - 135 c.

4. Стращенко И.Ю., Чилингарян Н.Р., Чубарина Ю.А. Роль физической подготовки в юридической деятельности // Международный журнал гуманитарных и естественных наук. 2018. №11-1. URL: https://cyberleninka.ru/article/n/rol-fizicheskoy-podgotovki-v-yuridicheskoy-deyatelnosti (дата обращения: 22.10.2020).

5. Шмыков В.И. Социально-психологические ресурсы психической устойчивости юристов // Вестник Пермского университета. Юридические науки. 2007. №8. URL: https://cyberleninka.ru/article/n/sotsialno-psihologicheskie-resursy-psihicheskoy-ustoychivosti-yuristov (дата обращения: 29.10.2020).

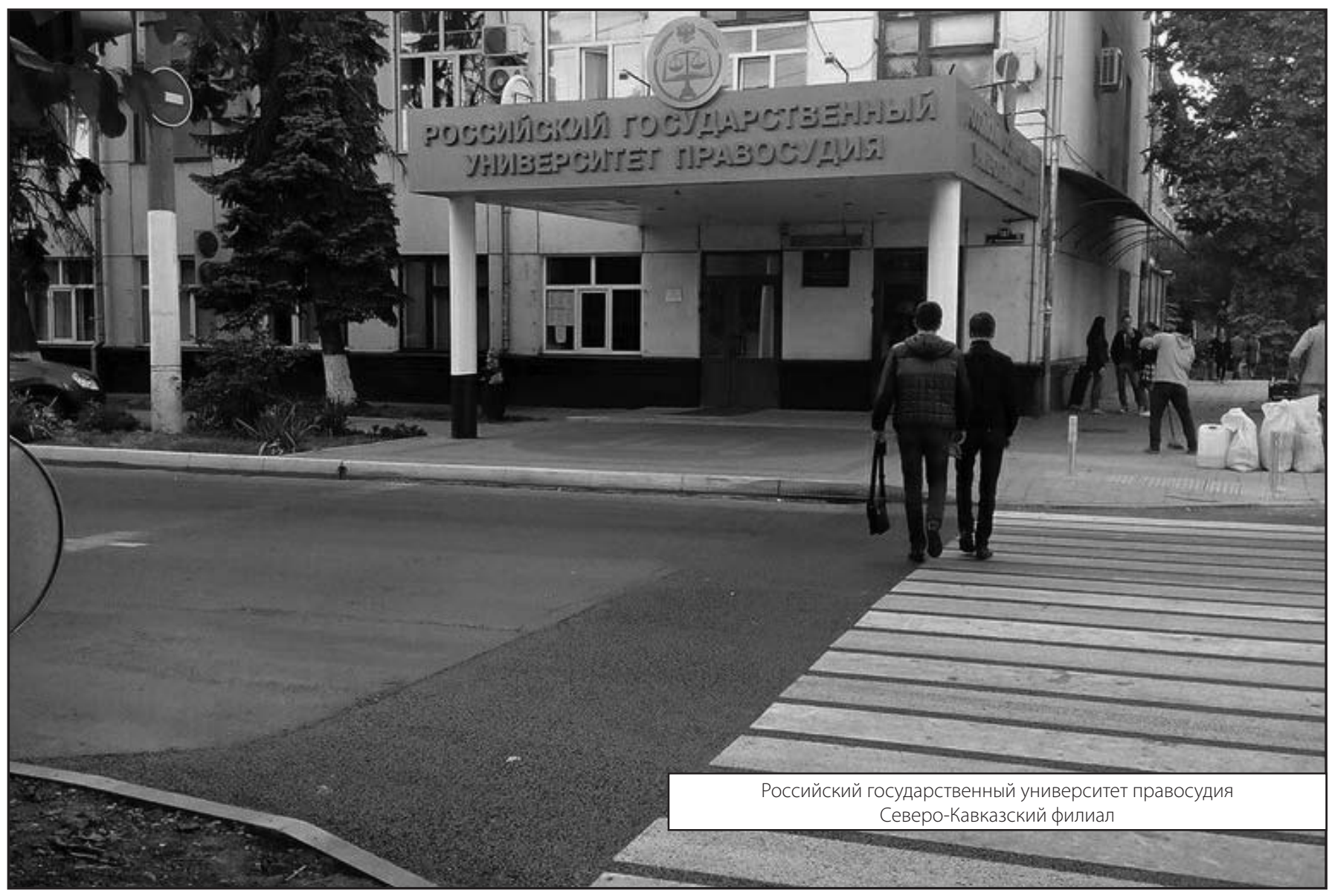

